\title{
Stability Analysis for Quality Traits in Durum Wheat (Triticum durum Desf) Varieties under Central Ethiopia
}

\author{
Mekuria Temtme $^{1 *}$ and Habtamu Tesfaye ${ }^{2}$ \\ ${ }^{1}$ DZARC, Debre Zeit Research Center, Ethiopia \\ ${ }^{2}$ EIAR, Ethiopia
}

\begin{abstract}
The present study was carried out to study stability performance over three locations for quality traits in 12 genotypes (9 exotic and 3 indigenous) of durum wheat using a randomized complete block design with three replications during 2018 and 2019. Ethiopian durum wheat varieties were studied using yield and quality traits including Grain yield, TKW, Hecto-litter weight, yellow pigment content, flour protein, wet and dry gluten, and SDS sedimentation test. Some stability parameters were used to express stable genotypes in relation to five quality traits. Some genotypes were stable for one quality trait and unstable for another, indicating that the genetic factors involved in g-e interactions vary between studied quality characteristics. The study of genotypic stability showed that the recently released variety "Utuba" had high stability for quality traits considered and proved to be the best among studied genotypes.
\end{abstract}

KEYWORDS: Durum wheat; Quality traits; Stability

\section{INTRODUCTION}

There are two types of wheat grown in Ethiopia: bread wheat (Triticum aestivum) and durum wheat (Triticum durum). Durum wheat is mostly grown in Ethiopia's highlands where it was introduced 5000 years ago. Farmers grow many local varieties of durum wheat (Triticum turgidum ssp. durum) because of both a natural evolution and farmers' domestication. Today, due to shifting rainfall and increasing temperature, the cultivation of durum wheat requires greater diversity of traits, which would, in turn, provide options for adaptation to new conditions.

Durum wheat generally including various shapes and sizes of spaghetti, macaroni, flat or corrugated sheets, used in lasagna, nodules, and other pasta shapes. Other products produced from durum wheat in Ethiopia include 'injera' (thin bread),'dabo' (Ethiopian bread), 'Dabo-kolo' (ground and seasoned dough shape and deep-fried), 'genfo' (Ethiopian porridge), 'kinche' (crushed kernel, very similar with couscous),' Nifro' (boiled whole grain sometimes mixed with pulses),' kolo' (roasted grain), and other food types and local beverages. The straw is mainly used as a source of animal feed.

Durum wheat quality traits follow a dynamic concept of stability, meaning that performance may change from environment to environment but in a predictable way (Becker and Leon 1988). According to this concept, genotypes with a small contribution to the genotype by environment variance $(G \times E)$ are more stable than genotypes with larger contributions. Genotypes, environments, and

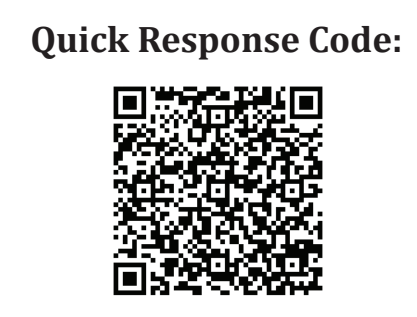

Address for correspondence: Mekuria Temtme, DZARC, Debre Zeit Research Center, Ethiopia

Received: July 09, $2021 \quad$ Published: July 23, 2021

How to cite this article: Mekuria Temtme, Habtamu Tesfaye. Stability Analysis for Quality Traits in Durum Wheat (Triticum durum Desf) Varieties under Central Ethiopia. 2021- 3(4) OAJBS. ID.000306. DOI: $10.38125 / \mathrm{OAJBS} .000306$ 
their interaction are known to have an influence on the quality traits of wheat grain. Inconsistent genotypic responses to environmental factors such as temperature, soil moisture, soil type, or fertility level from location to location and year to year are a function of genotype x environment (GE) interactions. Genotype x environment interactions have been defined as the failure of genotypes to achieve the same relative performance in different environments (Baker, 1988). Farmers are capable of meeting requirements concerning the production of high-quality wheat grains. However, the annual and local variation in both grain yield and quality can be considerable. The industries, however, demand a constant quality of the raw material. Letta et al., 2008 also indicated the stability of the quality of the raw material, designated as economic stability, guarantees constant procedures, and low product loss during processing. Hence, economic instability, as defined by the endusers, is caused by both environment and genotype-environment (g-e) interaction effects.

Several stability measures have been developed to assess the stability and adaptability of varieties. The most widely used is regression slope value and deviation from regression (S2d) Eberhart [1] and environmental variance, to multivariate methods (Purchase et al. developed the AMMI (The additive main effects and multiplicative interaction); [2,3].

The current investigation was carried out to evaluate the performance of durum wheat genotypes and to investigate their quality trait stability by some stability parameters across environments over two consecutive years.

\section{MATERIALS AND METHODS}

\section{Plant materials and experimental designs}

The experimental materials consist of twelve genotypes sourced from Ethiopia, ICARDA, CIMMYT, and a local check were evaluated during two cropping seasons (2018-2019) at three research sites (Table 1).

Table 1: Durum wheat cultivars included in the study.

\begin{tabular}{|c|c|c|}
\hline Code & Genotype Name & Origin \\
\hline G1 & Utuba & ICARDA \\
\hline G2 & Ude & CIMMYT \\
\hline G3 & Selam & CIMMYT \\
\hline G4 & Bekalcha & ICARDA \\
\hline G5 & LDRC 167 & Ethiopia \\
\hline G6 & Quamy & CIMMYT \\
\hline G7 & Werer & ICARDA/EIAR \\
\hline G8 & Asassa & CIMMYT \\
\hline G9 & Mangudo & ICARDA/EIAR \\
\hline G10 & ICAJIHAN2 & ICARDA/EIAR \\
\hline G11 & LDR164 & Ethiopia \\
\hline G12 & LDR302 & Ethiopia \\
\hline
\end{tabular}

Abbreviation: ${ }^{*}$ CIMMYT = International Centre for Wheat and Maize Improvement.

ICARDA = International Center for Agricultural Research in the Dry Areas.
The genotypes were grown in a randomized complete block design with four replications at each site. Plot size was $3 \mathrm{~m} 2,6$ rows with $2.5 \mathrm{~m}$ long, and $1.2 \mathrm{~cm}$ between rows. Where 4 rows harvested to estimate grain per plot and then converted to kg ha-1. At harvest, grain yield was determined for each genotype in each environment

Description of the experiment: The seed was drilled by hand at a seed rate of $125 \mathrm{~kg} /$ ha which is equivalent to $45 \mathrm{gm} / 3 \mathrm{~m}^{2}$ and planting depth was $\sim 5 \mathrm{~cm}$. Planting carried out at appropriate planting time for each location and fertilizer applied according to the specific recommendation.

\section{DESCRIPTION OF EXPERIMENTAL SITES}

The experiment conducted in six locations namely, Debrezeit, Chefe Donsa, and Akaki, representing different wheat-growing agro-ecologies of Ethiopia. Locations are representing the high land zone (1800-3000 Meters above sea level) and are received high rainfall (>750-1300mm) and drained to poorly drained black (vertisol) soils (Table 2).

\section{STATISTICAL PROCEDURES}

Combined analysis of variance on quality traits data from trials in six environments computed by ANOVA. The tests for quality evaluation performed on samples taken from replicated plots. Five stability parameters were applied to assess stability performance of genotypes and to identify superior genotypes; bi, the linear regression of the phenotypic values on the environmental index Finlay 1963, S2d, the deviation mean square from regression Eberhart [1], the stability variance d2i Shukla 1972, Wi, the ecovalence stability index Wricke 1964, and coefficient of determination (R2). All analysis was performed using the statistical package GEA-R and META R (Table 3).

\section{RESULTS AND DISCUSSIONS}

The first aim of the present study was to assess the quality trait stability and adaptability of durum wheat genotypes. A random sample of each harvested plot of genotypes was used for laboratory analysis. The analysis of variance revealed that the mean for genotypes and year were significant for all studied traits. Stability analysis of seed yield in different environments showed that the variance of genotypes and genotypes $\times$ environment interactions and mean squares of deviations from the regression were significant at $5 \%$ probability.

Based on genotypic stability, varieties such as Utuba, Selam, Mangudo, and ICAJIHAN2 confirmed high stability for the majority of quality traits. Based on Eberhart [1] a stable cultivar had a regression coefficient equal to or near the unity (one) and low or near the zero deviation from the regression mean square. There was no genotype with b-values equal to 1 . Similarly, some genotypes had a high deviation from regression and minimal for others (Table 3). Moreover, Letta 2008 suggested that the genetic factors involved in g-e interaction differed between traits. Widely adapted Variety "Utuba", released in 2015, revealed high stability for all of the quality traits except for protein content, SDS, and WGC. Other genotypes showed high stability for one trait and unstable for another trait which is going to be recommended for specific areas of the country. Local landraces "LRC302" and "LRC164" showed instability for the majority of quality traits except for HLW and protein content. However, besides instability, these landraces recommended being good crossing parent for future durum wheat national program because of having important resistant genes such 
as for fungal diseases like stem rust, yellow rust, and fusarium head blight and agronomic traits such as dwarfness, long coleoptile, early maturity, high protein content. Porcecldu 1973; Pacetti 1992 also showed that landraces are adapted to low fertility, high 1000 seed weight, and protein content $[4,5]$.
Utuba, a popular and widely adapted variety, especially in the mid and highlands of central Ethiopia, demonstrated high stability for yield and quality. This variety was "released as Ethiopian durum wheat variety in 2015 MoA [6] by Debrezeit Agricultural Research Center. Utuba is amber seeded, high protein content, and high yielding potential variety.

Table 2: Description of experimental sites.

\begin{tabular}{|c|c|c|c|c|c|c|c|}
\hline \multirow[b]{2}{*}{ Site } & \multicolumn{3}{|c|}{ Temperature(OC) } & \multirow{2}{*}{$\begin{array}{c}\text { Average } \\
\text { Annual Rain } \\
\text { fall }\end{array}$} & \multirow[b]{2}{*}{ Altitude } & \multirow[b]{2}{*}{ Latitude } & \multirow[b]{2}{*}{ Longitude } \\
\hline & Min & Average & Max & & & & \\
\hline Akaki & 8.3 & 16 & 25.2 & 1025 & 2280 & 8.9 & 38.76. \\
\hline Debre Zeit & 11.8 & 22.4 & 27.7 & 867.3 & 1860 & 8.71 & 38.95 \\
\hline Chefe Donsa & 9 & 19 & 28 & 1200 & 2460 & 8.97 & 39.12 \\
\hline
\end{tabular}

(250kg/ha of Urea and $200 \mathrm{~kg} / \mathrm{ha}$ of NPS (Nitrogen, Phosphorous, and Sulfur) of each location. Table 2. Description of experimental sites.

Table 3: Stability parameters for selected quality traits over twelve durum wheat genotypes.

\begin{tabular}{|c|c|c|c|c|c|}
\hline \multicolumn{6}{|c|}{ Dry Gluten content (DGC) } \\
\hline & \multicolumn{2}{|c|}{ Eberhart \& Russell } & \multicolumn{3}{|c|}{ Wricke's Ecovalence } \\
\hline Genotype & bi & S2di & $\mathrm{R} 2$ & DJi & Wi \\
\hline Utuba & 0.12 & 3.89 & 0.81 & 4.64 & 4.85 \\
\hline Ude & 0.54 & 35.77 & 0.29 & 36.51 & 41.19 \\
\hline Selam & 0.41 & 3.1 & 0.94 & 3.84 & 6.55 \\
\hline Bekalcha & 0.05 & -0.56 & 0.82 & 0.19 & 14.97 \\
\hline LRC167 & 0.57 & 30.94 & 0.51 & 31.68 & 34.69 \\
\hline Quamy & 0.45 & 12.41 & 0.89 & 13.16 & 17.99 \\
\hline Werer & 1.92 & 7.07 & 0.46 & 7.81 & 21.62 \\
\hline Asassa & -0.29 & -0.67 & 0.54 & 0.07 & 26.99 \\
\hline Mangudo & 1.21 & 9.16 & 0.5 & 9.9 & 10.59 \\
\hline ICAJIHAN2 & 0.29 & 2.45 & 0.88 & 3.19 & 11.5 \\
\hline LRC164 & 1.4 & 5.34 & 0.95 & 6.08 & 38.01 \\
\hline LRC302 & 1.34 & 5.66 & 0.7 & 6.4 & 8.29 \\
\hline \multicolumn{6}{|c|}{ Hectoliter weight (HLW) } \\
\hline Utuba & 0.53 & -1.16 & 0.98 & 0.01 & 0.14 \\
\hline Ude & 0.62 & -0.62 & 0.65 & 0.54 & 4.77 \\
\hline Selam & 0.83 & -1.16 & $0 . .65$ & 0.23 & 0.1 \\
\hline Bekalcha & 0.91 & -0.69 & 0.65 & 0.47 & 0.76 \\
\hline LRC167 & 0.47 & -0.08 & 0.85 & 1.07 & 9.05 \\
\hline Quamy & 0.45 & -0.87 & 0.56 & 0.29 & 0.93 \\
\hline Werer & 0.97 & -1.11 & 0.59 & 0.05 & 0.28 \\
\hline Asassa & 0.76 & -0.71 & 0.9 & 0.45 & 1.99 \\
\hline Mangudo & 0.5 & -0.4 & 0.45 & 0.75 & 0.87 \\
\hline ICAJIHAN2 & 0.7 & -0.34 & 0.66 & 0.81 & 0.82 \\
\hline LRC164 & 0.24 & -0.91 & 0.85 & 0.25 & 0.26 \\
\hline LRC302 & 0.26 & -0.91 & 0.36 & 0.25 & 0.26 \\
\hline
\end{tabular}




\begin{tabular}{|c|c|c|c|c|c|}
\hline \multicolumn{6}{|c|}{ Protein content (PRO) } \\
\hline Utuba & 0.05 & -0.02 & 0.99 & 0.04 & 0.91 \\
\hline Ude & -0.26 & -0.05 & 0.73 & 0 & 1.26 \\
\hline Selam & 0.46 & -0.05 & 0.93 & 0 & 0.17 \\
\hline Bekalcha & -0.29 & 0.84 & 0.96 & 0.9 & 2.2 \\
\hline LRC167 & 0.94 & 0.15 & 0.94 & 0.2 & 1.7 \\
\hline Quamy & 0.73 & 0.51 & 0.99 & 0.56 & 6.46 \\
\hline Werer & 0.01 & -0.05 & 0.7 & 0.01 & 0.79 \\
\hline Asassa & 0.29 & 0.84 & 0.96 & 0.9 & 1.3 \\
\hline Mangudo & 0.26 & 0.12 & 0.95 & 0.17 & 0.61 \\
\hline ICAJIHAN2 & 0.52 & 0.02 & 0.65 & 0.08 & 0.26 \\
\hline LRC164 & 0.97 & 0.01 & 0.59 & 0.06 & 0.07 \\
\hline LRC302 & 0.79 & -0.03 & 0.63 & 0.02 & 0.06 \\
\hline \multicolumn{6}{|c|}{ Sodium deosyl sulphate (SDS) } \\
\hline Utuba & 0.89 & -0.31 & 0.99 & 0.14 & 29.46 \\
\hline Ude & 0.97 & -0.04 & 0.99 & 0.41 & 246.22 \\
\hline Selam & -0.85 & 66.01 & 0.66 & 66.46 & 366.95 \\
\hline Bekalcha & 0.67 & 61.17 & 0.63 & 61.63 & 78.5 \\
\hline LRC167 & 0.62 & -0.09 & 0.98 & 0.36 & 5.65 \\
\hline Quamy & 0.96 & 1.49 & 0.97 & 1.95 & 3.63 \\
\hline Werer & 0.41 & -0.39 & 0.99 & 0.07 & 6.19 \\
\hline Asassa & 0.87 & 36.47 & 0.63 & 36.92 & 37.56 \\
\hline Mangudo & 0.03 & 58.83 & 0.7 & 59.28 & 59.32 \\
\hline ICAJIHAN2 & 0.19 & 9.12 & 0.63 & 9.58 & 33.72 \\
\hline LRC164 & -0.38 & 11.86 & 0.5 & 12.32 & 82.52 \\
\hline LRC302 & 0.75 & 113.63 & 0.5 & 114.09 & 134.93 \\
\hline \multicolumn{6}{|c|}{ Wet Gluten Content (WGC) } \\
\hline Utuba & 0.28 & 81.58 & 0.73 & 84.92 & 169.37 \\
\hline Ude & 0.75 & 211.92 & 0.7 & 215.26 & 306.71 \\
\hline Selam & 0.89 & 66.4 & 0.89 & 69.74 & 200.45 \\
\hline Bekalcha & -0.13 & 193.46 & 0.7 & 196.81 & 404.1 \\
\hline LRC167 & 0.18 & 474.06 & 0.64 & 477.41 & 587.49 \\
\hline Quamy & 0.79 & 91.22 & 0.52 & 94.56 & 101.44 \\
\hline Werer & 0.88 & 3.92 & 0.99 & 7.27 & 134.05 \\
\hline Asassa & -0.31 & 46.91 & 0.74 & 50.26 & 331.21 \\
\hline Mangudo & 0.03 & 130.77 & 0.57 & 134.12 & 134.3 \\
\hline ICAJIHAN2 & 0.58 & 6.3 & 0.85 & 9.65 & 38.57 \\
\hline LRC164 & 0.28 & 1.32 & 0.99 & 4.67 & 274.44 \\
\hline LRC302 & 0.76 & 158.37 & 0.76 & 161.71 & 256.44 \\
\hline
\end{tabular}




\begin{tabular}{|c|c|c|c|c|c|}
\hline \multicolumn{6}{|c|}{ Yellow pigment content (YPC) } \\
\hline Utuba & 0.95 & 0.09 & 0.71 & 0.19 & 0.22 \\
\hline Ude & 0.33 & 2.16 & 0.8 & 2.27 & 2.38 \\
\hline Selam & 0.93 & 4.45 & 0.71 & 4.55 & 4.83 \\
\hline Bekalcha & 0.8 & 1.52 & 0.98 & 1.63 & 3.68 \\
\hline LRC167 & 0.45 & -0.08 & 0.4 & 0.02 & 0.1 \\
\hline Quamy & 0.95 & 2.23 & 0.69 & 2.33 & 2.35 \\
\hline Werer & -0.75 & 1.17 & 0.7 & 1.28 & 3.25 \\
\hline Asassa & 0.5 & 0.05 & 0.71 & 0.16 & 0.22 \\
\hline Mangudo & 0.8 & 0.24 & 0.65 & 0.34 & 0.51 \\
\hline ICAJIHAN2 & -0.54 & 0.78 & 0.59 & 0.89 & 1.51 \\
\hline LRC164 & 0.01 & -0.1 & 0.39 & 0 & 0.26 \\
\hline LRC302 & 0.79 & -0.06 & 0.71 & 0.04 & 0.88 \\
\hline
\end{tabular}

The basic durum wheat quality criteria include high yield, high protein and yellow pigment content, strong gluten, and good pasta cooking quality Mohammed et al. [7]. The authors also emphasized that protein content and type in the grain of durum wheat is important for human nutrition and well-known quality criteria for pasta products. In addition, high protein determines premium prices for wheat in many regions of the world, making high grain protein content a primary target for durum wheat. All studied genotypes met international standards in terms of protein content (ranged from 14.5\%-18.37\%).

The popular semi-dwarf varieties (Utuba, Ude, Bekalcha, Werer and Mangudo) demonstrated moderately resistant to disease, high mean seed yield, very good quality for ((protein $>14.5 \%)$, yellow pigment content (>5.3\%), Hectoliter weight (>77.9 hL/l),1000 kernel weight(35.55gm), wet gluten $(>27.2 \%)$ and SDS volume (>37.9)). This indicates variety development was targeted with high yielding potential, durable resistance to rust disease, and better industrial quality. These stable, adaptable, high-yielding; and consumers preferred durum wheat varieties proved to be recommended for the high rainfall and optimum moisture (high potential) areas of the country [8].

The results of this work indicated that there were no cultivars stable for all quality characteristics. Comparable results were reported by other authors Rharbati et al. [9]. In a similar study by the genotype Waha was found to be stable for five out of the seven quality traits studied.

\section{CORRELATION BETWEEN TRAITS}

Grain yield per hectare showed a positive and significant association with harvest index, 1000-grain weight, Hectoliter weight, and SDS (Table 4). However, grain yield had negatively correlated with flour protein content and gluten strength. Several reports state that varietal differences in flour protein are inversely related to their grain and protein yielding abilities, resulting from an improvement of grain yield via enhanced assimilation and translocation of carbohydrates to the grain without a corresponding improvement in the remobilization of [10-13]. Flour protein showed statically significant and positive correlation with gluten strength $\left(\mathrm{r}=0.97^{* *}\right)$ and Wet gluten content $\left(\mathrm{r}=0.55^{* *}\right)$ but had negative and significant correlation with grain yield( $\left.\mathrm{r}=-0.59^{* *}\right)$, harvest index( $\left.\mathrm{r}=-0.61^{* *}\right), 1000$ kernel weight $\left(\mathrm{r}=-0.74^{* *}\right)$, hectoliter litter weight $\left(\mathrm{r}=-0.71^{* *}\right)$. A similar founding was also reported. Yellow pigment content, an important parameter for semolina quality, had no significant association with all tested quality traits except SDS. Dry gluten content had positively and strongly correlated with wet gluten content $\left(\mathrm{r}=0.99^{* *}\right)$; (Table 4$)$.

Table 4: Correlation coefficients of mean values of yield and quality traits of varieties represented in the study.

\begin{tabular}{|c|c|c|c|c|c|c|c|c|c|c|}
\hline Traits & GY & HI & TKW & HLW & Glu & Pro & Wgc & Dgc & SDS & YPC \\
\hline GY & 1 & & & & & & & & & \\
\hline $\mathrm{HI}$ & $0.85^{* *}$ & 1 & & & & & & & & \\
\hline TKW & $0.87^{* *}$ & $0.99 * *$ & 1 & & & & & & & \\
\hline HLW & 0.53 & $0.73^{* *}$ & $0.65^{* *}$ & 1 & & & & & & \\
\hline Glu & -0.4 & -0.33 & -0.47 & $-0.60^{* *}$ & 1 & & & & & \\
\hline Pro & $-0.59 * *$ & $-0.61^{* *}$ & $-0.74^{* *}$ & $-0.71^{* *}$ & $0.96^{* *}$ & 1 & & & & \\
\hline Wgc & 0.1 & 0.06 & -0.51 & -0.33 & $0.63^{* *}$ & $0.55^{* *}$ & 1 & & & \\
\hline Dgc & 0.19 & -0.01 & -0.37 & -0.4 & 0.55 & 0.47 & $0.99 * *$ & 1 & & \\
\hline SDS & $0.82^{* *}$ & $0.71^{* *}$ & $0.61^{* *}$ & 0.38 & -0.2 & -0.26 & $0.54^{* *}$ & 0.35 & 1 & \\
\hline YPC & 0.1 & -0.23 & -0.46 & -0.04 & -0.25 & -0.1 & -0.43 & -0.45 & $0.34^{* *}$ & 1 \\
\hline
\end{tabular}




\section{CONCLUSION}

Twelve durum wheat genotypes, including three checks, were evaluated during two cropping seasons (2018-2019) at three research sites, representative of major durum wheat-producing areas of Ethiopia. Stability parameters were applied to assess stability performance of genotypes and to identify superior genotypes; bi, the linear regression of the phenotypic values on the environmental index, $\mathrm{S} 2 \mathrm{~d}$, the deviation mean square from regression, and coefficient of determination. Based on genotypic stability, varieties such as Utuba, Selam, Mangudo, and ICAJIHAN2 demonstrated high stability for the majority of quality traits. Studied genotypes showed high stability for one trait and unstable for another trait. Therefore, it is important to recommend the best genotypes in quality traits for a specific environment. Local landraces "LRC302" and "LRC164" showed stability for HLW and protein content. Besides stability, they could be good crossing parent for future durum wheat national program because of having important resistant genes for fungal diseases such as stem rust, yellow rust, and fusarium head blight and for agronomic traits such as dwarfness, long coleoptile, early maturity, high protein content, and adaptation to low fertility. Finally, data generated from an experiment conducted on three locations may not be sufficient to find out stable genotypes for all quality traits. Therefore, data from many years are preferred to make reliable recommendations.

\section{ACKNOWLEDGEMENT}

we would like to thank the Ethiopian Institute of Agricultural Research (EIAR) for its financial support. We also greatly acknowledge all collaborators for their assistance in the execution of the multi-environment field experiments.

\section{REFERENCES}

1. Eberhart SA, Russel WA (1966) Stability parameters for comparing varieties. Crop Sci 6: 36-40.

2. Mohammed A, Geremew B, Amsalu A (2012) Variation and associations of quality parameters in Ethiopian durum wheat (Triticum turgidum
L. var. durum) Genotypes. International Journal of Plant Breeding and Genetics 6: 17-31.

3. Baker RJ (1988) Tests for cross over genotype $\mathrm{x}$ environment interactions. Can J Plant Sci 68: 405-410.

4. Grausgruber HM, Oberforester M, Werteker P, Rucken Bauer, Vollmann J (2000) Stability of quality traits in Austrian-grov $\backslash$ Tll winter wheats. Field Crops Res 66: 257-267.

5. Korkut KZ, Bilgin O, Başer İ, Sağlam N (2007) Stability of grain vitreousness in durum wheat (Triticum durum Desf.) genotypes in the North-Western Region of Turkey. Turk J Agric 31: 313-318.

6. MoA (2016) Ministry of agriculture, plant variety release, protection and seed quality control directorate, crop variety register, Addis Ababa, Ethiopia.

7. Mohammadi M, Karimizadeh R, Hossinpour T, Falahi HA, Khanzadeh $H$ (2012) Genotype $\times$ Environment Interaction and Stability Analysis of Seed Yield of Durum Wheat Genotype in Dryland Conditions. Notulae Sci Bio 4(3): 57-64.

8. Obsa C (2014) Genetic variability among bread wheat (Triticum aestivum L.) genotypes for growth characters, yield and Yield components in bore district, Oromia regional state. Agriculture, Forestry and Fisheries 6(6): 188-189.

9. Rharrabti Y, Garcia del Moral LF, Villegas D, Royo C (2003) Durum wheat quality in Mediterranean environments III. Stability and comparative methods in analyzing G x E interaction. Field Crops Research 80: 141146.

10. Roemer T (1917) Sind die ertragreichen Sorten ertragssicherer Mitteihmgen der Deutschen Land wirtschaftlichen Gesellschaft 32: 8789.

11. Sourour A, Afef Salah B (2018) Corrilation between agronomic and quality traits in durum wheat (Triticum durum Desf.) germplasm in semiarid environment. Adv plants Agri Res 612-615.

12. Stewart DW, Dwyer LM (1990) Yields and protein trends of spring wheat (Triticum aestivum L.) on the Canadian prairies. Canadian Journal of Plant Science 70: 33-44.

13. Zobel RW, Wright MJ, Gauch HG (1988) Statistical analysis of yield trial. Agron J 80: 388-393. 